\title{
Correction to: Effects of reading interventions implemented for upper elementary struggling readers: a look at recent research
}

\section{Rachel E. Donegan ${ }^{1}$ (D) Jeanne Wanzek ${ }^{2}$}

Published online: 23 June 2021

(c) Springer Nature B.V. 2021

\section{Correction to: Reading and Writing https://doi.org/10.1007/s11145-021-10123-y}

In the original publication of the article, the formatting of the last column of Table 1 was incorrectly displayed. This has been corrected with this Correction.

Rachel Donegan: Formerly at Department of Special Education, Peabody College of Education and Human Development, Vanderbilt University.

The original article can be found online at https://doi.org/10.1007/s11145-021-10123-y.

Rachel E. Donegan

rdonegan@niu.edu

1 Department of Special and Early Education, College of Education, Northern Illinois University, 1425 West Lincoln Hwy., DeKalb, IL 60115, USA

2 Department of Special Education, Peabody College of Education and Human Development, Vanderbilt University, Nashville, TN, USA 
Table 1 Intervention descriptions and outcomes

Intervention Descriptions and Outcomes

\begin{tabular}{|c|c|c|c|c|c|}
\hline Study & $\begin{array}{l}\text { Selection Criteria } \\
\text { Avg. Performance at Pretest** }\end{array}$ & Intervention Description & Outcomes & \multicolumn{2}{|c|}{ Contrast } \\
\hline $\begin{array}{l}\text { Benner, } \\
2007\end{array}$ & $\begin{array}{l}\text { Identified by school as not } \\
\text { responsive to core instruction or } \\
\text { interventions. } \\
\text { Avg. Found.: } 88.88\end{array}$ & $\begin{array}{l}\text { T: Phonics, word identification, and } \\
\text { fluency intervention supplanting core } \\
\text { reading instruction } \\
\text { C: General education classroom reading } \\
\text { instruction }\end{array}$ & $\begin{array}{l}\text { Found. } \\
\text { WR \& S } \\
\text { Fluency }\end{array}$ & & \\
\hline $\begin{array}{l}\text { Bennett et } \\
\text { al., } 2015\end{array}$ & $\begin{array}{l}\text { Below grade level on the state } \\
\text { standardized test and identified by } \\
\text { school as poor readers }\end{array}$ & $\begin{array}{l}\mathrm{T} \text { : Computerized program incorporating } \\
\text { repeated reading } \\
\text { C: Typical school reading instruction }\end{array}$ & Comp. & \multicolumn{2}{|c|}{$\frac{\mathrm{T} \text { vs C }}{0.60}$} \\
\hline $\begin{array}{l}\text { Cirino et } \\
\text { al., } 2017\end{array}$ & $\begin{array}{l}\text { Standard score } \leq 90 \text { on the GMRT } \\
\text { reading comp. subtest } \\
\text { Avg. Found.: } 87.85 \\
\text { Avg. Comp.: } 79.43\end{array}$ & $\begin{array}{l}\text { T1: Vocab. and comp. instruction using } \\
\text { readings of state history } \\
\text { T2: T1 plus instruction in executive } \\
\text { functioning and self-regulated learning } \\
\text { C: Typical school reading instruction }\end{array}$ & Comp.* & $\frac{\text { T1 vs C }}{.37}$ & $\frac{\mathrm{T} 2 \mathrm{vs} \mathrm{C}}{.25}$ \\
\hline $\begin{array}{l}\text { Connor et } \\
\text { al., } 2018\end{array}$ & $\begin{array}{l}\text { Standard score }<98 \text { on the } \\
\text { Expressive One Word Picture } \\
\text { Vocabulary Test } \\
\text { Avg. Found.: } 97.5 \\
\text { Avg. Comp.: } 85.50\end{array}$ & $\begin{array}{l}\text { T1: Sensorimotor simulations of abstract } \\
\text { concepts with instruction in language, } \\
\text { reading comp., and writing } \\
\text { T2: Explicit instruction in expository text } \\
\text { structure using signal words } \\
\text { C: Typical school reading instruction }\end{array}$ & $\begin{array}{l}\text { Found. } \\
\text { WR \& S } \\
\text { Fluency } \\
\text { Comp. } \\
\text { Comp* }\end{array}$ & $\begin{array}{c}\text { T1 vs C } \\
0.04 \\
-0.01 \\
0.06 \\
0.01 \\
-0.09\end{array}$ & $\begin{array}{c}\text { T2 vs C } \\
-0.06 \\
-0.07 \\
-0.06 \\
0.07 \\
-0.01\end{array}$ \\
\hline $\begin{array}{l}\text { Das et al., } \\
2008\end{array}$ & $\begin{array}{l}\text { Scored } \leq 1 \text { standard deviation below } \\
\text { the mean on word identification or } \\
\text { pseudoword reading tests } \\
\text { Avg. Found.: } 83.35\end{array}$ & $\begin{array}{l}\mathrm{T} \text { : General strategy use and specific } \\
\text { application to reading and spelling } \\
\mathrm{C} \text { : Phonics tasks compiled by the school } \\
\text { resource teacher }\end{array}$ & $\begin{array}{l}\text { Found. } \\
\text { PA } \\
\text { WR \& S }\end{array}$ & & \\
\hline
\end{tabular}

Das et al., Scored $\leq 12$ months below expected T: Cognitive training tasks (repetition, 1995 age on WRMT word identification joining, sequencing, matching,

Study 1 or word attack subtest and had lower verification, and memorizing) both with than average scores in an area of and without words

Found. cognitive processing.

$\mathrm{C}$ : Typical school reading instruction

Das et al., Scored $\leq 12$ months below expected T1: Cognitive training tasks (repetition, 1995 age on WRMT word identification joining, sequencing, matching,

Study 2 or word attack subtest and had lower verification, and memorizing) without than average scores in an area of words. cognitive processing.

Fuchs et Identified by school as at risk for al., 2018 reading difficulties, scored $>13^{\text {th }}$ and $<30^{\text {th }}$ percentile on the TOWRE, Sight Word Efficiency subtest, $<60^{\text {th }}$ percentile on the reading comp. Iowa Test of Basic Skills, reading comp. subtest, and earned a T-score $>37$ on the Weschler Abbreviated Scale of Intelligence vocab. or matrix reasoning subtest Avg. Found.: 94.00

Keller et Identified with a learning disability al., 2019 by school

T2: Identical to T1 except training tasks were completed with words

$\mathrm{C}$ : Previously trained on tasks with and without words

T1: Before and after reading strategies focused on comp. of informational text T2: T1 plus activities to strengthen working memory

$\mathrm{C}$ : Typical school reading instruction

T: Computerized training in phonics, phonemic awareness, spelling, and fluency and teacher-led instruction in decoding, text reading strategies, and mindfulness

$\mathrm{C}$ : Computerized training in phonics, phonemic awareness, spelling, and fluency and teacher-led phonetic and orthographic activities
WR \& S

0.06

$\underline{\text { T1 vs C } \quad \underline{T 2} \text { vs C }}$

Found.

WR \& S $\quad 0.35 \quad-0.03$

$\begin{array}{lcc} & \text { T1 vs C } & \text { T2 vs C } \\ \text { Comp. } & 0.56 & 0.64 \\ \text { Comp.* } & 1.02 & 1.08\end{array}$

\section{$\underline{\text { T vs C }}$}

Found.

WR \& S* $\quad 1.07$ 
Table 1 (continued)

Kim et al., Below proficient on the state 2011 reading assessment

Kim et al., Below proficient on the state 2010 reading assessment

Avg. Found.: 91.77

Avg. Comp.: 91.34

Mason et Identified by school as having

al., 2013 difficulty with writing and reading comp. and scored in lowest range on state reading and writing tests

Mathes \& Identified with a learning disability Fuchs, in reading, received reading

1993 instruction in a special education setting, had IEP objectives in reading, and had an instructional reading level between primer and one grade below their grade level

Miciak et Standard score $\leq 85$ on the GMRT al., 2018 Avg. Found.: 85.59

Avg. Comp.: 79.43

O'Connor $\operatorname{Read}<80$ words per minute on et al., 2002 beginning second-grade text and scored $<2.2$. grade equivalent on the WRMT

Avg. Found.: 82.28

Avg. Comp.: 89.36

O'Connor Read 20-80 word per minute on

et al., 2007 grade level passages and earned a standard score $>69$ on the PPVT

Avg. Found.: 89.49

Avg. Comp.: 87.86

Reed et al., Below grade level benchmarks on

$2019 \quad$ Fall and Winter FASTBridge Oral Reading Fluency assessment

Ring et al., Below grade level oral reading rate 2012 and either below proficient on state reading assessment or below grade level on the Texas Primary Reading Inventory

Avg. Found.: 97.20

Avg. Comp.: 97.81
T: After-school intervention with whole group comp. and vocab. lessons, and computer-based individualized practice with found. and comp. skills

C: Typical district after-school program

T: After-school intervention program with small group fluency, comp., and decoding lessons; independent reading, and computer-based individualized practice with found. and comp. skills

C: Typical district after-school program

T1: Self-regulated strategy development in comp. strategies for before, during, and after reading

T2: T1 plus informative paragraph writing instruction

$\mathrm{C}$ : Access to instructional passages

T1: Peer tutoring using repeated reading T2: Peer tutoring using continuous reading

$\mathrm{C}$ : Typical school reading instruction

Found.

Fluency $\quad-0.52$

$\underline{\text { T2 vs C }}$

0.37

Comp.

$-0.33$

T1: Two-year reading intervention with vocab., individualized word study, text reading, and comp. instruction using social studies texts; year 1 outcomes $\mathrm{T} 2$ : One-year reading intervention identical to $\mathrm{T} 1$

T3: Two-year reading intervention identical to T1 with added self-regulation and goal setting; year 2 outcomes C: Typical school reading instruction

T1: Phonemic awareness, phonics and word analysis, fluency building, comp. strategies, and integrated spelling or writing using instructional level reading materials

T2: Identical to T1 except reading materials matched general education classroom

C: Typical school reading instruction

T1: Repeated reading

T2: Continuous reading with same text as $\mathrm{T} 1$

Found

$\underline{\text { T1 vs C }}$ T2 vs C

C: Typical school reading instruction

$\begin{array}{lll}\text { WR \& S } & 0.75 & 0.34\end{array}$

Fluency

$\begin{array}{lll}\text { Fluency* } & 0.78 & 0.66\end{array}$

Comp. 0.99

$\mathrm{T}$ : Summer reading program with whole individualized to student need, and

WR \& S

C: No summer reading program comp

Comp. 
Table 1 (continued)

Ritchey et Identified with $\geq 40 \%$ probability of $\mathrm{T}$ : Comp. strategies, fluency, vocab., and

al., 2012 reading risk using reading assessments and teacher rating scales

Avg. Found.: 85.32

Avg. Comp.: 86.54

decoding strategies instruction using

science texts with embedded

motivational components

C: Typical school reading instruction only

Ritchey et Identified with difficulties in reading $\mathrm{T}$ : Comp. and decoding strategies

al., 2017 comp. by school and scored $<30^{\text {th }}$ percentile on the TOSREC Avg. Comp.: 84.6 instruction using science texts C: Typical school reading instruction only

T1: After-school intervention with individualized computerized and small group lessons focused on word reading, fluency, and comp.

T2: After-school reading intervention with computerized instruction and small group lessons focused on text reading and comp.

$\mathrm{C}$ : No after-school reading intervention

Swanson Standard score $>70$ on PPVT and $\& \quad$ read $<85$ words per minute on a

O'Connor grade level passage

2009 Avg. Found.: 91.21

Avg. Comp.: 81.25

Thames et Lowest quartile of performance on

al., 2008 state reading assessment

T1: Repeated reading of connected texts $\mathrm{T} 2$ : Continuous reading of connected texts.

$\mathrm{C}$ : Typical school reading instruction

$\mathrm{T}$ : Individualized instruction in vocab. and comp. strategies supplanting core reading instruction

$\mathrm{C}$ : Typical school reading instruction

Therrien, Identified with a learning disability $\mathrm{T}$ : Passages matched to student et al., 2006 in reading or at risk for reading failure and had instructional reading level of first to fourth grade. Avg. Found.: 81.66 performance read two to four times to meet fluency criterion and comp. questions answered with scaffolding C: Typical school reading instruction

Torgesen Identified with a learning disability $\mathrm{T}$ : Focused on phonemic awareness, et al., 2001 by school, scored $\geq 1.5$ standard encoding, and decoding at the word deviations below average on WRMT level. word attack and word identification $\mathrm{C}$ : Focused on word recognition and subtests, and performed below grade fluency, phonics and oral reading with level on phonological awareness test text comp. with practice split equally of Lindamood assessment. between word and text level.

Avg. Found.: 71.25

Avg. Comp.: 79.48

Toste et Identified by their schools as the

al., 2019 lowest performing readers not receiving intensive reading interventions and scored $<25^{\text {th }}$ percentile on either subtest of the TOWRE

Avg. Found.: 91.43

Avg. Comp.: 88.72

Vadasy \& Scored at-risk on DIBELS and were T: Fluency with repeated reading, Sanders identified by their teachers as having vocab., and comp. instruction using 2008 low fluency or comp. Avg. Found.: 88.82 Avg. Comp.: 79.43
T1: Focused on vowel sounds, decoding spelling, and fluency with multisyllabic words

T2: T1 plus motivational beliefs training $\mathrm{C}$ : Typical school reading instruction nonfiction science and social studies passages

$\mathrm{C}$ : Typical school reading instruction

$\begin{array}{lc} & \frac{T \text { v C }}{\text { Found. }} \\ \text { WR \& S } & 0.21 \\ \text { WR \& S* } & 0.01 \\ \text { Fluency } & 0.55 \\ \text { Comp. } & 0.23 \\ \text { Comp.* } & -0.09 \\ & 0.31\end{array}$

Found

Fluency $\quad-0.09$

Comp. $\quad 0.20$

Comp.* 0.73

Comp. $\frac{\text { T1 vs C }}{-0.03} \quad \frac{\text { T2 vs C }}{-0.12}$

\begin{tabular}{lll} 
& T1 vs C & $\frac{\text { T2 vs C }}{-0.52}$ \\
Found. & -0.33 & -0.62 \\
WR \& S & -0.41 & -0.33 \\
Fluency & -0.16 & -0.18 \\
Comp. & -0.15 & T1 vs C \\
Comp.* & \multicolumn{2}{c}{0.55}
\end{tabular}

WR \& S

Fluency $\quad 0.04$ 
Table 1 (continued)

\begin{tabular}{|c|c|c|c|c|c|c|}
\hline $\begin{array}{l}\text { Vaughn et } \\
\text { al., } 2016\end{array}$ & $\begin{array}{l}\text { Standard score } \leq 85 \text { on the GMRT } \\
\text { Avg. Found.: } 85.59 \\
\text { Avg. Comp.: } 88.68\end{array}$ & $\begin{array}{l}\text { T: Vocab., comp., fluency and } \\
\text { individualized multisyllabic word study } \\
\text { C: Typical school reading instruction }\end{array}$ & $\begin{array}{l}\text { Found. } \\
\text { WR \& S } \\
\text { Fluency } \\
\text { Comp. }\end{array}$ & & $\begin{array}{l}\text { T vs } \\
-0.05 \\
-0.08 \\
0.05 \\
-0.11\end{array}$ & \\
\hline $\begin{array}{l}\text { Vaughn, et } \\
\text { al., } 2019\end{array}$ & $\begin{array}{l}\text { Standard score } \leq 85 \text { on the TOSREC } \\
\text { Avg. Found.: } 86.66\end{array}$ & $\begin{array}{l}\text { T: Word study, fluency, and comp. } \\
\text { instruction with self-regulation } \\
\text { components including goal-setting and } \\
\text { comp. monitoring } \\
\text { C: Typical school reading instruction }\end{array}$ & $\begin{array}{l}\text { Found. } \\
\text { WR \& S } \\
\text { WR \& S* } \\
\text { Fluency } \\
\text { Comp. }\end{array}$ & & $\begin{array}{l}\text { T vs } \\
0.19 \\
0.12 \\
0.48 \\
0.27 \\
0.07\end{array}$ & \\
\hline $\begin{array}{l}\text { Wanzek \& } \\
\text { Roberts } \\
2012\end{array}$ & $\begin{array}{l}\text { Identified as at high risk for reading } \\
\text { disabilities by school and scored } \leq \\
25^{\text {th }} \text { percentile on comp. subtest of } \\
\text { the GMRT } \\
\text { Avg. Found.: } 93.88 \\
\text { Avg. Comp.: } 82.17\end{array}$ & $\begin{array}{l}\text { T1: Multicomponent intervention with a } \\
\text { focus on word recognition } \\
\text { T2: Multicomponent intervention with a } \\
\text { focus on comp. instruction } \\
\text { T3: Intervention above according to area } \\
\text { of need } \\
\text { C: Typical school reading instruction }\end{array}$ & $\begin{array}{l}\text { Found. } \\
\text { WR \& S } \\
\text { Comp. }\end{array}$ & $\begin{array}{c}\text { T1 vs C } \\
\\
-0.04 \\
0.27\end{array}$ & $\begin{array}{c}-0.13 \\
0.29\end{array}$ & $\begin{array}{l}-0.03 \\
-0.02\end{array}$ \\
\hline $\begin{array}{l}\text { Wanzek et } \\
\text { al., } 2017\end{array}$ & $\begin{array}{l}\text { Scored } \leq 30^{\text {th }} \text { percentile on the } \\
\text { reading comp. subtest of the GMRT }\end{array}$ & $\begin{array}{l}\text { T: Phonics and word recognition, } \\
\text { fluency, vocab., and comp. with a focus } \\
\text { on text reading and comp. after the first } 6 \\
\text { weeks } \\
\text { C: Typical school reading instruction }\end{array}$ & $\begin{array}{l}\text { Found. } \\
\text { WR \& S } \\
\text { Comp. }\end{array}$ & & $\begin{array}{c}-0.05 \\
0.11\end{array}$ & \\
\hline $\begin{array}{l}\text { Xin \& } \\
\text { Rieth, } \\
2001\end{array}$ & $\begin{array}{l}\text { Identified with a disability and } \\
\text { receiving special education reading } \\
\text { instruction }\end{array}$ & $\begin{array}{l}\text { T: Video and class discussion used to } \\
\text { teach content vocab. } \\
\text { C: Dictionaries and class discussion used } \\
\text { to teach content vocab. }\end{array}$ & Comp.* & & $\frac{\mathrm{T} \text { vs C }}{0.34}$ & \\
\hline $\begin{array}{l}\text { Young et } \\
\text { al., } 2015\end{array}$ & $\begin{array}{l}\text { Score below proficiency on a school } \\
\text { assessment and identified by the } \\
\text { school as demonstrating the greatest } \\
\text { reading need }\end{array}$ & $\begin{array}{l}\text { T: Fluency with texts adjusted according } \\
\text { to student performance using neural } \\
\text { impress method and repeated reading } \\
\text { with brief comp. } \\
\text { C: Typical school reading instruction } \\
\text { only }\end{array}$ & $\begin{array}{l}\text { Found. } \\
\text { Fluency } \\
\text { Fluency* } \\
\text { Comp. }\end{array}$ & & $\begin{array}{l}0.16 \\
0.74 \\
0.36\end{array}$ & \\
\hline
\end{tabular}

Note. $\mathrm{T}=$ Treatment $\mathrm{C}=$ Comparison; Avg. = Average; Found. = Foundational; $\mathrm{PA}=$ Phonological awareness; $\mathrm{WR} \& \mathrm{~S}=\mathrm{W}$ ord reading and spelling; Comp. $=$ Comprehension; Vocab. $=$ Vocabulary; GMRT $=$ Gates-MacGinitie Reading Test; WRMT = Woodcock Reading Mastery Test; TOWRE = Test of Word Reading Efficiency; TOSREC $=$ Test of Silent Reading Efficiency and Comprehension; PPVT = Peabody Picture Vocabulary Test; * denotes unstandardized outcome; ** average performance at pretest was determined using available standard scores

$T$ treatment, $C$ comparison, Avg. average, Found. Foundational, $P A$ phonological awareness, $W R \& S$ word reading and spelling, Comp.comprehension, Vocab. vocabulary, GMRT gates-MacGinitie Reading Test, $W R M T$ woodcock reading mastery test, TOWRE test of word reading efficiency, TOSREC test of silent reading efficiency and comprehension, $P P V T$ peabody picture vocabulary test

*Unstandardized outcome

${ }^{* *}$ Average performance at pretest was determined using available standard scores

Publisher's Note Springer Nature remains neutral with regard to jurisdictional claims in published maps and institutional affiliations. 